\title{
The influence of salt-sensitivity on the blood pressure daily profile in patients with arterial hypertension
}

\author{
S. A. Yermolenko, V. F. Orlovskyi, I. O. Moiseyenko, O. V. Orlovskyi
}

Sumy State University, Medical Institute, Sumy, Ukraine

Corresponding author. E-mail: sa.ermolenko@med.sumdu.edu.ua

Paper received 23.06.20; Accepted for publication 16.07.20.

\section{https://doi.org/10.31174/SEND-NT2020-244VIII30-09}

\begin{abstract}
Arterial hypertension is one of the main causes of cardiovascular mortality in the world and affects almost $25 \%$ of the adult population. The aim was to determine the blood pressure daily profile depending on the type of salt-sensitivity in patients with stage II arterial hypertension. Materials and methods. 120 individuals aged 30-75 years with stage II arterial hypertension and 50 practically healthy individuals (control group) were enrolled to the study. Weinberger M. N. method was used to determine the type of salt-sensitivity. The essence of this method is to stick to a high-salt diet during 5 days with the salt consumption of $15 \mathrm{~g}$ per day ( 250 mmol sodium), with a further restriction on salt intake to $2 \mathrm{~g}$ per day (up to $50 \mathrm{mmol}$ sodium) for 5 days (low-salt diet). The systolic blood pressure decrease by more than 10 $\mathrm{mm} \mathrm{Hg}$ after switching from a high-salt to low-salt diets. Level of the blood pressure was the diagnostic criterion for salt-sensitivity. Patients were classified as salt-resistant included patients whose systolic blood pressure did not decrease by more than $10 \mathrm{~mm} \mathrm{Hg}$ during the study and individuals with a paradoxical reaction to the change in salt load and a increase in systolic blood pressure during the switching to a lowsalt diet. Daily blood pressure monitoring was performed according to the standard protocol. Results. $42.5 \%$ of salt-sensitive and $47.5 \%$ of salt-resistant patients were identified. The blood pressure daily profile distribution showed that $76.5 \%$ of «non-dippers» and $15.6 \%$ of «nightpeakers» were among salt-sensitive, and $73.7 \%$ of «dippers» and $19.3 \%$ of «non-dippers» - among salt-resistant patients. Salt-sensitive patients have nighttime blood pressure dipping more than 2 times less than control $(\mathrm{p}<0.001)$. This matches to the type of «non-dippers» daily profile. This is prognostically unfavorable. Salt-sensitive patients have the 24 -hour mean variability systolic and diastolic blood pressure values are significantly higher than in the other groups. The morning increase in blood pressure analysis revealed that values in both groups remained unchanged and corresponded to control group. Salt-sensitive patients had increased 24-hour mean rate of morning increase in systolic blood pressure, systolic blood pressure time index, and blood pressure variability values in comparison with salt-resistant patients. Conclusions. Salt-sensitive patients are characterized by a predominance of the «non-dippers» and «night-peakers», enlarged rate of morning increase in blood pressure, increased blood pressure variability, and the lowest degree of nighttime blood pressure dipping, which is prognostically unfavorable for the arterial hypertension course. Salt-resistant patients have a favorable blood pressure daily profile - «dippers» and the reference values of daily profile parameters.
\end{abstract}

Keywords: arterial hypertension, salt-sensitivity, blood pressure daily profile.

Introduction. Arterial hypertension $(\mathrm{AH})$ is one of the main causes of cardiovascular mortality in the world and affects almost $25 \%$ of the adult population. It is predicted an increase of $\mathrm{AH}$ prevalence to 1.5 billion people in 2025 , and $13.5 \%$ of the total premature mortality. There will be $54 \%$ of events caused by stroke and $47 \%$ - by ischemic heart disease. [1-3].

The first clinical works about the harmful effects of salt on human body appeared in the early twentieth century (L. Ambard, E. Beaujard (1904), W. Kempner (1948)), which made it possible to consider salt abuse as one of the $\mathrm{AH}$ major risk factors [4-6]. Epidemiological studies have shown that high salt intake is associated with an increased risk of cardiovascular events and reduced sodium intake along with increased potassium intake can significantly reduce blood pressure (BP). Namely, the results of multicenter studies (INTERSALT, DASH, NUTRICODE) showed that salt intake limited to $6 \mathrm{~g}$ per day is accompanied by a drop of 6 $10 \mathrm{mmHg}$ in SBP. Also, it reduces cardiovascular mortality by $16 \%$ and stroke risk by $23 \%$ [7-9]. Referring to a thorough evidence base, the World Health Organization (WHO) points to the pronounced association between salt consumption and $\mathrm{AH}$ and appeals to reduce $\mathrm{NaCl}$ consumption in order to decrease CVD and stroke mortality $[10,11]$.

It has been established that renal dysfunction (namely impaired sodium excretion) plays a role in the salt-sensitive $\mathrm{AH}$ genesis $[12,13]$. The glomerular filtration decrease is accompanied by the "nocturnal $\mathrm{BP} /$ diurnal $\mathrm{BP}$ " ratio increase and the prevalence of "non - dipper" type correlates with creatinine clearance. This suggests that an adverse prognosis for salt-sensitive $\mathrm{AH}$ also depends on the $\mathrm{BP}$ daily profile characteristics $[14,15]$.
The purpose of this study was to determine the BP daily profile depending on the salt-sensitivity type in patients with stage II AH.

Materials and methods. 120 individuals aged 30-75 years with stage II AH were involved in the study (38.3\% of males and $61.7 \%$ of females). The control group included 50 practically healthy individuals (29 females and 21 males; mean age $42.2 \pm 4.5$ ).

Verification of the diagnosis $\mathrm{AH}$ were estimated according to the criteria of the Ministry of Health of Ukraine unified clinical protocol № 564 (dated 13.06.2016) [16]. All patients gave a voluntary informed written consent.

Exclusion criteria were the presence of symptomatic $\mathrm{AH}$, myocardial infarction or unstable angina, effort angina II-IV functional classes, diabetes mellitus, acute infectious diseases, exacerbation of chronic infectious diseases, neoplasms, mental disorders and nervous system diseases, systemic connective tissue diseases, acute disorders of cerebral circulation and the refusal to participate in the study.

The type of salt-sensitivity was determined using Weinberger M. N. (1986) technique. The essence of this method is to stick to a high-salt diet during 5 days with the salt consumption of $15 \mathrm{~g}$ per day ( $250 \mathrm{mmol}$ sodium), with a further restriction on salt intake to $2 \mathrm{~g}$ per day (up to $50 \mathrm{mmol}$ sodium) for 5 days (low-salt diet). Sticking to a diet was estimated by daily urinary sodium excretion during high-salt $(\mathrm{Na} \geq$ $230 \mathrm{mmol} /$ day) and low-salt ( $\mathrm{Na} \leq 20 \mathrm{mmol} /$ day) diets using ion-selective urine potentiometry. Office blood pressure measurement was carried out in the morning on the last day of diet. The SBP decrease by more than $10 \mathrm{mmHg}$ after switching from a high-salt to low-salt diets using the office blood pressure measurement was the diagnostic criterion for salt-sensitivity. Patients were classified as salt-resistant in- 
cluded patients whose SBP did not decrease by more than 10 $\mathrm{mm} \mathrm{Hg}$ during the study and individuals with a paradoxical reaction to the change in salt load and a increase in SBP during the switching to a low-salt diet [17].

Daily monitoring of BP (DMBP) was performed using the TM ABRM 04 (MeditechLtd., Hungary), according to the standard protocol [18]. The Medibase 1.42 program was used for DMBP data analysis. The following parameters were analyzed: diurnal, nocturnal and 24-hour mean values of SBP $\left(\mathrm{SBP}_{24}, \mathrm{SBP}_{\mathrm{d}}, \mathrm{SBP}_{\mathrm{n}}\right)$ and diastolic $\mathrm{BP}(\mathrm{DBP})\left(\mathrm{DBP}_{24}\right.$, $\left.\mathrm{DBP}_{\mathrm{d}}, \mathrm{DBP}_{\mathrm{n}}\right)$; parameters of "pressure load" - time indices (TI AH), the degree of nighttime BP dipping (DND ${ }_{\mathrm{SBP}}$ and $\mathrm{DND}_{\mathrm{DBP}}$, respectively), as well as the diurnal and nocturnal BP variability (VAR) (SBP: VAR $\mathrm{SBP}_{\mathrm{d}}, \mathrm{VAR}_{\mathrm{SBP}}$; DBP: $\mathrm{VAR} \mathrm{DBP}_{\mathrm{d}}, \mathrm{VAR}_{\mathrm{DBP}}$ ). It was used the 24-hour mean SBP and $\mathrm{DBP}$ threshold level $\geq 130 / 80 \mathrm{mmHg}$ for $\mathrm{AH}$ diagnosing. The TI AH SBP $\geq 20 \%$ and TI AH DBP $\geq 10 \%$ values were considered as transient increase in $\mathrm{BP}$, the diurnal and nocturnal TI AH $\geq 50 \%$ - as steady increase in BP. The AH circadian rhythm was evaluated by the degree of nighttime SBP and DBP dipping, which allows to estimate the BP 24hour rhythm amplitude. The following types of BP 24-hour rhythms were distinguished using the DND BP: patients with a $\mathrm{SBP}_{\mathrm{n}}$ decreased by 10-20\% were classified as "dippers", by $10 \%$ - "non-dippers", by more than $20 \%$ - "over dippers". In the presence of nocturnal hypertension (BP > $125 / 75 \mathrm{mmHg}$ ), patients were enrolled in «night-peakers» [18].

For statistical results were performed using the methods of biostatistics implemented in the package of SPSS version 21(SPPS for Windows, version 21, SPPS Inc., Chicago, IL).We used statistical methods for nonparametric indicators due to abnormal distribution. The values of the studied indicators are given in the form of the median with interquartile range. The probability of differences for comparison of quantitative values was determined using the Mann - Whitney method (p). Differences were considered statistically significant at $\mathrm{p}<0.05$.
Results. According to the type of salt-sensitivity, patients were divided into 2 groups: salt-sensitive $(n=51 ; 42.5 \% ; 12$ males and 39 females) and salt-resistant $(n=57 ; 47.5 \% ; 32$ males and 25 females). 12 patients had a paradoxical reaction to the salt load, which didn't allow them to enter any of the groups.

Salt-sensitive and salt-resistant patients were found to have the higher 24-hour mean SBP and DBP values than the control group $(\mathrm{p}<0.001)$, but do not differ from each other $(\mathrm{p}=0,13)$ (Table 1).

The daily increase in blood pressure (DI BP) was evaluated by the degree of BP dipping. It was found the "dippers" 4 cases $(7.8 \%)$, "non-dippers" - 39 (76.5\%), "over-dippers" $0(0 \%)$ and "night-peakers" - $8(15.7 \%)$ among salt-sensitive patients. Also, there were 44 «dippers» $(77.2 \%), 11$ «nondippers» $(19.3 \%), 2$ «over-dippers» $(3.5 \%)$ and 0 «nightpeakers» $(0 \%)$ among salt-resistant patients. Either, saltresistant patients have higher DND BP than control group. This corresponds to a prognostically favorable «dippers» type. Salt-sensitive patients have DND BP more than 2 times less than control ( $\mathrm{p}<0.001)$. This matches to the type of «non-dippers» daily profile. This is prognostically unfavorable; its causes are not fully understood. According to the M. Fukuda et al. [19] hypothesis, pressure natriuresis, which provides sodium excretion in the BP salt-sensitivity, has a certain daily rhythm. Thus, in the daytime, the efficiency of this mechanism decreases, which causes sodium retention and extracellular fluid accumulation. In the nighttime, the efficiency of pressure natriuresis increases, and the sodium balance becomes negative, returning to normal in the morning. Therefore, M. Fukuda and co-authors consider "nondippers" as a homeostatic phenomenon of maintaining a zero sodium balance under conditions of impaired natriuresis. Indeed, «non-dippers» appears in the salt-sensitive AH patients with high salt intake and disappear in the case of lowsalt diet [19]. Also, it can be corrected by diuretics [20].

Table 1. 24-hour mean parameters of BP monitoring in $\mathrm{AH}$ patients with different types of BP salt-reactivity

\begin{tabular}{|c|c|c|c|}
\hline \multirow[t]{2}{*}{ Parameter } & \multirow{2}{*}{$\begin{array}{l}\text { Control } \\
(n=50)\end{array}$} & \multicolumn{2}{|l|}{ AH patients $(n=108)$} \\
\hline & & Salt-sensitive $(n=51)$ & Salt-resistant $(n=57)$ \\
\hline SBP, $\mathrm{mmHg}$ & $120,7(118,9-124,9)$ & $157,6(153,3-162,9) \mathrm{p} 1<0,001$ & $154,2(148,5-157,8) \mathrm{p} 1<0,001 ; \mathrm{p} 2=0,13$ \\
\hline $\mathrm{DBP}, \mathrm{mmHg}$ & $70,4(68,4-76,4)$ & $98,7(94,5-101,6) \mathrm{p} 1<0,001$ & $98,2(90,6-101,4) \mathrm{p} 1<0,001 ; \mathrm{p} 2=0,001$ \\
\hline DND SBP, $\%$ & $15,8(14,5-17,0)$ & $5,6(4,3-6,4) \mathrm{p} 1<0,001$ & $16,4(14,7-18,1) \mathrm{p} 1=0,076 ; \mathrm{p} 2<0,001$ \\
\hline DND DBP, $\%$ & $14,7(13,1-16,1)$ & $5,7(5,2-6,2) \mathrm{p} 1<0,001$ & $15,1(13,6-16,8) \mathrm{p} 1=0,076 ; \mathrm{p} 2<0,001$ \\
\hline VAR SBP, mmHg & $11,5(10,5-12,35)$ & $17,5(15,7-19,1) \mathrm{p} 1<0,001$ & $8,4(7,8-9,4) \mathrm{p} 1=0,076 ; \mathrm{p} 2<0,001$ \\
\hline VAR DBP, $\mathrm{mmHg}$ & $8,7(8,2-9,6)$ & $16,4(14,7-18,2) \mathrm{p} 1<0,001$ & $8,6(7,9-9,5) \mathrm{p} 1=0,076 ; \mathrm{p} 2<0,001$ \\
\hline MI SBP, $\mathrm{mmHg}$ & $38,3(36,1-40,2)$ & $36,8(34,6-38,0) \mathrm{p} 1<0,001$ & $48,8(47,6-50,8) \mathrm{p} 1=0,076 ; \mathrm{p} 2<0,001$ \\
\hline MI DBP, mmHg & $28,9(27,0-30,9)$ & $26,7(25,3-28,4) \mathrm{p} 1<0,001$ & $29,7(28,5-31,6) \mathrm{p} 1=0,076 ; \mathrm{p} 2<0,001$ \\
\hline RMI SBP, mmHg & $8,1(6,4-9,0)$ & $16,1(15,2-17,1) \mathrm{p} 1<0,001$ & $8,4(7,6-9,3) \mathrm{p} 1=0,76 ; \mathrm{p} 2<0,001$ \\
\hline RMI DBP, $\mathrm{mmHg}$ & $4,5(3,7-5,4)$ & $10,4(9,5-11,3) \mathrm{p} 1<0,001$ & $4,6(3,4-5,8) \mathrm{p} 1=0,75 ; \mathrm{p} 2<0,001$ \\
\hline TI AH SBP, $\%$ & $16,0(10,0-20,0)$ & $78,5(74,0-84,0) \mathrm{p} 1<0,001$ & $67,0(63,0-70,7) \mathrm{p} 1<0,001 ; \mathrm{p} 2<0,001$ \\
\hline TI AH DBP, $\%$ & $8,0(6,0-10,0)$ & $81,0(76,0-85,0) \mathrm{p} 1<0,001$ & $65,0(61,0-72,0) \mathrm{p} 1<0,001 ; \mathrm{p} 2<0,001$ \\
\hline
\end{tabular}

Annotation: $\mathrm{BP}_{\mathrm{d}}$ - diurnal mean parameter; $\mathrm{BP}_{\mathrm{n}}$ - nocturnal mean parameter; $\mathrm{p} 1$ - comparison with the control group, $\mathrm{p}<0,001 ; \mathrm{p} 2$ comparison between groups of examined patients, $\mathrm{p}<0,001$.

According to the obtained data, it was revealed that saltsensitive patients have the 24-hour mean VAR SBP and VAR DBP values and the 24-hour mean SBP and DBP values more than normal (15 and $14 \mathrm{mmHg}$, respectively). They are significantly higher than in the other groups ( $\mathrm{p}$ $<0.001$ ). The 24-hour variability of blood pressure does not change or exceed the norm in salt-resistant patients. It is possible to assume that natriuretic hormones are activated in the daytime and relatively suppressed in the nighttime in saltsensitive AH. Therefore, the pressure natriuresis daily rhythm is probably related to the fluctuation of sympathoadrenal system (SAS) and the reninangiotensin system (RAS) activities [20]. The MI BP analysis revealed that values in both groups remained unchanged and corresponded to control group ( $\mathrm{SBP} \geq 56.5 \mathrm{mmHg}$ and $\mathrm{DBP} \geq 36 \mathrm{mmHg}$ ). In addition, salt-sensitive patients have the MI SBP and DBP 
values lower than salt-resistant patients $(\mathrm{p}<0.001)$. It can be explained by the monotonic 24-hour BP variability. That's why MI BP is not informative. The rate of morning increase in blood pressure (RMI) is significantly higher in saltsensitive patients $(\mathrm{p}<0.001)$. The parameters of salt-resistant patients don't differ from the control group $(\mathrm{p}=0.7)$.

TI AH is the parameter that forms the DI BP. The 24-hour mean TI AH for SBP and DBP in patients with AH is significantly higher than in healthy individuals $(\mathrm{p}<0.001)$. It doesn't depend on salt-sensitivity.

It is known that the increase in 24-hour mean SBP and DBP, RMI BP, as well as a decrease in DND BP have the greatest prognostic value for the AH complications [19]. The most adverse DMBP parameters are inherent in the sodiumsensitive AH. In our opinion, this may be one of the explanations for unfavorable prognosis under conditions of BP saltsensitivity.

\section{Conclusions.}

1. It was identified $42.5 \%$ of salt-sensitive and $47.5 \%$ of saltresistant cases among the examined patients with stage II AH.

2. Salt-sensitive patients are characterized by a predominance of the «non-dippers» $(76.5 \%)$ and «night-peakers» $(15.7 \%)$ BP daily profiles. Also, they had the enlarged rate of morning increase in $\mathrm{BP}$, increased $\mathrm{BP}$ variability, and the lowest degree of nighttime BP dipping, which is prognostically unfavorable for the $\mathrm{AH}$ course.

3. «Dippers» (77.2\%) are more common for salt-resistant patients. This group has a favorable BP daily profile and reference values for morning increase in $\mathrm{BP}$, rate of morning increase in BP and BP variability, which did not differ from the control group.

\section{LITERATURE}

1. Волошина I.M. Менеджмент споживання кухонної солі при артеріальній гіпертензії// Патологія,2018. 15, № 1(42), С. 122-126.

2. Imaizumi Y, Eguchi K, Murakami T et al. High salt intake is independently associated with hypertensive target organ damage// The Journal of Clinical Hypertension. 2016, 18, P. 315-321

3. Elijovich, F., Weinberger, M.H., Anderson, C.A. et al. Salt sensitivity of blood pressure: a scientific statement from the american heart association// Hypertension, 2016. 68(3), P. 7-46. doi: 10.1161/HYP.0000000000000047.

4. Grillo, A., Salvi, L., Coruzzi, P. et al. Sodium intake and hypertension// Nutrients, 2019. 11(9), doi: 10.3390/nu11091970.

5. Фатула М.І., Машура Г.Ю. Артеріальна гіпертензія і хлорид натрію// Науковий вісник Ужгородського університету, серія «Медицина», 2015.1 (51), С. 259-265.

6. Rust, P., Ekmekcioglu, C. Impact of salt intake on the pathogenesis and treatment of hypertension// Adv Exp Med Biol, 2017. 956, P. 61-84. doi: 10.1007/5584.

7. Äijälä, M., Malo, E., Santaniemi, M. et al. Dietary sodium intake and prediction of cardiovascular events. Eur J Clin Nutr, 2015. 69(9), P. 1042-7.doi: 10.1038/ejcn.2015.40.

8. Iwahori, T., Miura, K., Ueshima, H. et al. INTERSALT Research Group. Urinary sodium-to-potassium ratio and intake of sodium and potassium among men and women from multiethnic general populations: the INTERSALT Study// Hypertens Res, 2019.17, doi: 10.1038/s41440-019-0263-1.

9. Juraschek, S.P., Miller, E.R., Weaver, C.M. et al. Effects of sodium reduction and the DASH diet in relation to baseline blood pressure// J Am Coll Cardiol, 2017. 70(23), P. 2841-2848. doi: 10.1016/j.jacc.2017.10.011.

10. World Health Organization. A global brief on hypertension: silent killer, global public health crisis // World Health Day 2013. Report. Geneva, Switzerland: World Health Organization, 2013. P. 1-39.

11. Norm, R.C., Campbell, M.D., Correa-Rotter. R, et al. Proposed nomenclature for salt intake and for reductions in dietary salt // J. Clin. Hypertens. (Greenwich), 2015. 17(4), P. 247-251.

1. Voloshyna, I.M. Menedzhment spozhyvannya kuxonnoyi soli pry arterialnij gipertenziyi [Management of salt intake in hypertension]// Patology, 2018. 15 - 1(42), P. 122-126.

5. Fatula, M.I., Mashura, G.Yu. Arterialna gipertenziya i xloryd natriyu. [Hypertension and sodium chloride]. Scientific bulletin of Uzhgorod University, series "Medicine", 2015. 1 (51), P. 259265.

12. Babkyin, A.P., Gladkix, V.V., Kurbatova, T.L.. Solechuvstvitelnost arterialnoj gipertenzii kak prediktor эffektivnosti antigipertenzivnoj terapii. [The salt sensitivity of arterial hypertension as a predictor of the effectiveness of antihypertensive thera-

12. Бабкин

А.П., Гладких В.В. Курбатова Т.Л Солечувствительность артериальной гипертензии как предиктор эффективности антигипертензивной терапии // Международный медицинский журнал, 2010. 3, С. $49-52$.

13. Kantaria, N., Pantsulaia, I., Andronikashvili, I., et al. Possible mechanism of development of salt setsitive essential hypertension//Georgian Med News, 2016. 258, P. 28-32.

14. Kario, K., Tomitani, N., Kanegae, H., et al. Comparative effects of an angiotensin II receptor blocker (ARB)/diuretic vs. $\mathrm{ARB} /$ Calcium-Channel Blocker combination on uncontrolled nocturnal hypertension evaluated by information and communication technology-based nocturnal home blood pressure monitoring- the NOCTURNE study// Circ J, 2017.81(7), P. 948-957. doi: 10.1253/circj.CJ-17-0109.

15. Mente, A., O'Donnell, M., Rangarajan, S., et al. Associations of urinary sodium excretion with cardiovascular events in individuals with and without hypertension: a pooled analysis of data from four studies// The Lancet, 2016. 388 (10043), P. 465-475.

16. Уніфікований клінічний протокол первинної, вторинної (спеціалізованої) та третинної (високоспеціалізованої) медичної допомоги. Профілактика серцево-судинних захворювань. Затверджено Наказом Міністерства охорони здоров'я України від 13.0.2016 року № 564.

17. Weinberger, M.H., Fineberg, N.S., Fineberg, E., Weinberger, M.. Salt sensitivity, pulse pressure, and death in normal and hypertensive humans// Hypertens, 2001. 37(2), P. 429-432.

18. Гусаров Г. В. Добове моніторування артеріального тиску та його оцінка / I - Medic : статті / Г. В. Гусаров. - Київ, 2012. C. $1-4$.

19. Kimura, G.I., Dohi, Y., Fukuda, M.. Salt sensitivity and circadian rhythm of blood pressure: the keys to connect CKD with cardiovascular events// Hypertens Res, 2010. 33(6), P. 515-520. doi: 10.1038/hr.2010.47.

20. Fukuda, M.I., Yamanaka, T., Mizuno, M., et al. Angiotensin II type 1 receptor blocker, olmesartan, restores nocturnal blood pressure decline by enhancing daytime natriuresis// J Hypertens, 2008. 26(3), P. 583-588. doi: 10.1097/HJH.0b013e3282f2fded.

\section{REFFERENCES}

16. Unifikovaniy klinichniy protokol pervinnoyi, vtorinnoyi (spetsializovanoyi) ta tretinnoyi (visokospetsializovanoyi) medichnoyi dopomogi. Profilaktika sertsevo-sudinnih zahvoryuvan, № 564 vid 13.07.2016 roku. [Unified clinical protocol of primary, secondary (specialized) medical and tertiary (highly specialized) medical care. Prevention of cardiovascular diseases.№564 dated 13.07.2016].

18. Gusarov, G.V. Dobove monitoruvannya arterialnogo tysku ta jogo ocinka [Daily blood pressure monitoring and evaluation] Kiev: I-Medic, 2012. P.1-4. 